学術論文

\title{
大気圧プラズマ処理培地が培養大腸癌細胞に与える影響
}

\section{Effect of Medium Irradiated with Atmospheric Pressure Plasma on Cultured Colorectal Cancer Cells}

\author{
高橋 玄宇（正員），奥野 菜々子 (学生員)，森 晃，和多田 雅哉（正員）
}

Genu TAKAHASHI (Mem.), Nanako OKUNO (Stu. Mem.), Akira MORI, Masaya WATADA (Mem.)

\begin{abstract}
Several studies have reported the use of atmospheric pressure plasma irradiation for medical applications. Atmospheric pressure plasmas produced under atmospheric pressure, so they contain many neutral molecules, ions, and radicals. Radicals are highly reactive and have the property of damaging cancer cells. We have previously studied the effects of plasma-treated water irradiated with atmospheric pressure plasma on the colon cancer model rats. In this study, we investigated the mechanism of suppression of cancer progression by irradiating the culture medium of colon cancer cells with atmospheric pressure plasma.
\end{abstract}

Keywords: atmospheric pressure, colorectal cancer, cancer therapy.

(2020 年 11 月 30 日受付, 2021 年 4 月 13 日再受付)

\section{1 緒言}

プラズマの医療分野への応用は，主として止血，焼 灼，滅菌などに利用されてきた。しかし近年，プラズ マの医療分野への応用の広がりとして，大気圧低温プ ラズマを用いた治療法の検討が多くなされている。ア メリカのDrexel 大学ではプラズマを糖尿病性壊死の治 療に用いる研究を行っており, 同大学では自然治癒が 難しいと診断された糖尿病性壊死の病変部に対してプ ラズマを照射し，その経過を評価した[1]。その結果， 病変部の治癒促進が観察され，2 カ月後に完治した。 治瘉促進の理由として，プラズマ照射により細胞成長 因子及び損傷した細胞に刺激が加わり，自己細胞が増 殖した結果，治療効果が表れたと考えられる。

一方，名古屋大学では組織ではなく細胞を対象とし て，がん治療に対する大気圧プラズマを用いた治療法 についても研究されている。同大学では大気圧プラズ マ処理を行った培地に癌細胞を暴露させることで，特 異的な細胞分子内機構により癌細胞を死滅させる等の 報告がある[2]。

現在，世界全体で年間 960 万人ががんにより亡くな っている。日本人のがん死亡率は 1980 年に脳血管疾 患を抜いて死因第一位となった。2019年の年間死亡者 数は 38 万人を超えてさらに増加傾向を示しているた 連絡先：高橋 玄宇, 干158-0087 東京都世田谷区玉堤 128-7, 東京都市大学 工学部 医用工学科,

e-mail: gtakaha@tcu.ac.jp

東京都市大学
め，有効ながん治療の確立が求められている[3-4]。特 に，我が国におけるがんの部位別死亡者数では，大腸 癌の罹患率は男性が 3 位，女性が 1 位と非常に高い。 大腸癌の代表的な治療法には，内視鏡治療，開腹手術 や腹腔鏡下手術といった外科治療, 薬物療法等がある。 大腸がんの病期が浅ければ手術で取り除くことが可能 であるが，進行していた場合は薬物療法や対処療法が 選択される。また，内視鏡治療以外の治療法ではいず れも侵襲性が高く，患者の負担が大きい点が特に問題 である。そこで我々は，低侵襲な治療法という観点か ら，大気圧低温プラズマを用いた大腸癌の新規治療法 について検討した。

大気圧低温プラズマは通常のプラズマとは異なり, 大気圧下で生成されるため，真空装置の簡略化や大気 の組成分子を利用した様々な活性分子の生成が可能で ある。大気圧低温プラズマによって生成される代表的 な分子としては，中性分子，イオン，ラジカル，一酸 化窒素などの窒素酸化物が含まれる。それらの分子は 活性が高く，がん細胞に対して有用であるが，通常の 上皮細胞に対して障害を与える危険性もある。そこで 本研究では，ヒト結腸腺癌細胞 COLO 205 及びマウス 頭蓋冠細胞 MC3T3-E1 を用いて大気圧低温プラズマ照 射培地の暴露による評価を行った。 


\section{2 実験方法}

\section{1 大気圧低温プラズマの組成分析}

本実験に用いる大気圧プラズマ発生装置の概要を Fig. 1 に，プラズマ発生条件及び使用機器一覧を Table 1,2 に示す[5]。プラズマ発生部では He ガス中のタン グステン電極とグランド電極間に電圧を印加すること で，大気圧下においてプラズマを発生させた。

大気圧低温プラズマが細胞に与える影響を調査す るためには，生成されたプラズマの組成分析が必要で ある。そこで本研究では，ガラスキャピラリー先端か ら放出される光を小型ファイバ入力式マルチチャンネ ル分光器 (USB2000+, Ocean Optics,Inc) を用いて計測 した。分光計測条件は波長帯域が 260 270 nm, 波長分 解能が $0.38 \mathrm{~nm}$ である。プラズマ発生時の印加電圧は $8 \mathrm{kV}$, その他の条件は Table 1 に準じて照射を行った。

また，照射されたプラズマによって培養液中に生成 された分子の一種である，過酸化水素の濃度をデジタ ルパックテスト (DPM-H202, 協立理化学研究所) を用 いて測定した。測定時の印加電圧は $8 \mathrm{kV}, 13 \mathrm{kV}$ とした。 過酸化水素は水溶液中できわめて強い酸化力をもつ七 ドロキシラジカルを生成しやすい[6]。従って，過酸化 水素の濃度を調査することで，大気圧低温プラズマに よる細胞増殖の抑制経路の特定が可能である。

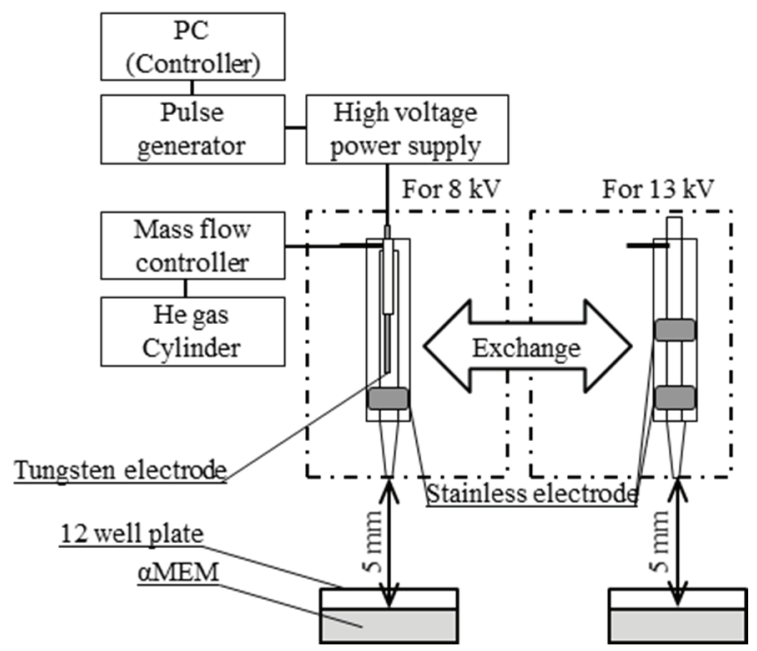

Fig. 1 Schematic of view in measurement of plasma irradiation.

Table 1 Parameters in measurement of plasma flow.

\begin{tabular}{|c|c|c|c|c|c|}
\hline Gas & Flow rate & $\begin{array}{c}\text { Applied } \\
\text { voltage }\end{array}$ & $\begin{array}{c}\text { Fre- } \\
\text { quency }\end{array}$ & $\begin{array}{c}\text { Wave } \\
\text { form }\end{array}$ & $\begin{array}{c}\text { Inhalation } \\
\text { time }\end{array}$ \\
\hline $\mathrm{He}$ & $1.0 \mathrm{~L} / \mathrm{min}$ & $8.13 \mathrm{kV}$ & $3 \mathrm{kHz}$ & Square & $90 \mathrm{sec}$ \\
\hline
\end{tabular}

2.2 正常細胞に対する大気圧低温プラズマ照射培地の 暴露評価

大気圧低温プラズマの細胞への影響を調査する方法 として，照射した細胞の細胞増殖曲線を作成し，増殖 能を評価することが挙げられる。そこで我々は正常細 胞である MC3T3-E1 細胞を用いて，大気圧プラズマが 通常細胞の細胞増殖に与える影響を評価した。実験の 際には 12 well 培養容器 (ポリプロピレン製: $6 \mathrm{~cm}^{2} / \mathrm{well}$ ) 上に 10\% Fatal Bovine Serum (FBS) (Thermo Fisher Scientific, Inc.) 含有 Alpha modification of Eagle's MEM ( $\alpha$ MEM）（Thermo Fisher Scientific, Inc.) 培地を $1 \mathrm{~mL}$ ずつ添加し，大気圧プラズマ照射装置先端のガラスキ ヤピラリー先端より $5 \mathrm{~mm}$ の距離を置いて照射した。 また，プラズマ照射時の印加電圧を変更することで照 射結果に差が生じると考え，印加電圧を $8 \mathrm{kV}$ 及び 13 $\mathrm{kV}$ で設定して実験を行った。その後, MC3T3-E1 細胞 を 12 well 培養容器上に $1.0 \times 10^{5}$ cells $/ \mathrm{mL}$ ずつ播種し, $37^{\circ} \mathrm{C}, \mathrm{CO}_{2}$ 濃度 $5 \%$ で培養した。大気圧低温プラズマを MC3T3-E1 細胞に照射し，12，24，48，72 時間後に各 well に対して $0.5 \mathrm{~mL}$ の 0.05\% Trypsin-EDTA を加えて 細胞を遊離した。遊離した細胞を $1500 \mathrm{rpm}$ で 5 分間遠 心して回収し，血球計算盤で細胞数を計算した。対照 実験群として，大気圧低温プラズマを生成する際に必 要な Heのみを照射した群と比較を行った。

2.3 大腸癌細胞に対する大気圧低温プラズマ照射培地 の暴露評価

大気圧低温プラズマが大腸癌に与える影響を調査 するため, ヒト結腸腺癌細胞由来である COLO 205 細 胞を用いて大気圧プラズマ照射培地の評価を行った。 実験の際には 12 well 培養容器上に $10 \% \mathrm{FBS}$ 含有 RPMI1640（Thermo Fisher Scientific, Inc.）培地を $1 \mathrm{~mL}$ ずつ添加し，その後の処置は 2.2 節と同様に行った。

Table 2 Used apparatuses in measurement of plasma flow.

\begin{tabular}{|l|l|l|}
\hline Apparatus & Manufacturer & Name of product \\
\hline Pulse Generator & NF Corporation & $\begin{array}{l}\text { WAVE FACTORY } \\
1941\end{array}$ \\
\hline $\begin{array}{l}\text { High Voltage Power } \\
\text { Supply }\end{array}$ & NF Corporation & HVA4321 \\
\hline Mass Flow Controller & KOFLOC & 8500 MC-0-1-1 \\
\hline
\end{tabular}


2.4 大腸癌細胞に対する大気圧低温プラズマ照射培地 及び過酸化水素添加培地への暴露評価

2.1 節で行った組成分析から, COLO 205 細胞に対し てプラズマを照射した培地, 及び同濃度の過酸化水素 を添加した培地を用いて増殖能を比較した。実験の際 には 12 well 培養容器上に 10\%FBS 含有 RPMI1640 培 地を $1 \mathrm{~mL}$ ずつ添加し, 大気圧プラズマ照射装置先端 のガラスキャピラリー先端より $5 \mathrm{~mm}$ の距離を置いて 照射した。また, 過酸化水素暴露群として, 過酸化水 素を終濃度 $1.05 \mathrm{mg} / \mathrm{L}$ となるよう培地に添加した。そ の後の細胞への処置は 2.2 節と同様である。照射時の 印加電圧は $13 \mathrm{kV}$, 対照実験群として大気圧低温プラ ズマを生成する際に必要な $\mathrm{He}$ のみを照射した群と比 較を行った。

2.5 大腸癌細胞に対する大気圧低温プラズマ照射培地 暴露群の炎症性サイトカイン比較

大気圧低温プラズマが COLO 205 細胞に与える影響 を調査するため, Real-time polymerase chain reaction（リ アルタイム PCR）法を用いた遺伝子発現解析により炎 症性サイトカインの発現量を比較した。本研究では, 炎症性サイトカインの指標として TNF- $\alpha$ を用いた。 $T N F-\alpha$ は腫瘍壊死因子と呼ばれ, 細胞に対して侵襲的 なダメージが生じた際に速やかに分泌される，最も一 般的な生体反応のシグナル伝達物質である。TNF- $\alpha$ は 生体に対して炎症反応, 細胞分化におけるシグナルパ スウェイの活性化といった様々な反応を示すが，特に アポトーシスを誘因することが広く知られている[7]。 従って, 大気圧低温プラズマを照射した COLO 205 細胞の TNF- $\alpha$ の発現量を対照群と比較することで, 細 胞内で生じている現象についての調査が可能である。

実験の際には 12 well 培養容器上に $10 \% \mathrm{FBS}$ 含有 RPMI1640 培地を $1 \mathrm{~mL}$ ずつ添加し, 大気圧プラズマ照 射装置先端のガラスキャピラリー先端より $5 \mathrm{~mm}$ の距 離を置いて照射した。その後, COLO 205 細胞を 12 well 培養容器上に $1.0 \times 10^{5}$ cells $/ \mathrm{mL}$ ずつ播種し, $37^{\circ} \mathrm{C}, \mathrm{CO}_{2}$ 濃度 5\%で培養した。大気圧低温プラズマをCOLO 205 細胞に照射し，24，48，72，96 時間後に各 wellに対し て $800 \mu \mathrm{L}$ の ISOGENE（NIPPON GENECo,.Ltd.）を添 加し, 細胞を回収した。 RNA フリー水 $320 \mu \mathrm{L}$ を加え

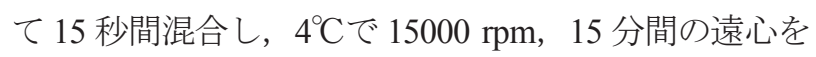
行った。上清 $800 \mu \mathrm{L}$ を回収し, 再度 $15000 \mathrm{rpm}$ で遠心 した。沈殿に $0.5 \mathrm{~mL}$ のイソプロパノールを $1 \mathrm{~mL}$ 添加
し， $12000 \mathrm{rpm}$ で 5 分 $4^{\circ} \mathrm{C}$ で遠心した。上清を除去し, $70 \%$ エタノール $1 \mathrm{~mL}$ を加えて $12000 \mathrm{rpm}$ で 5 分間 $4{ }^{\circ} \mathrm{C}$ で遠心した。エタノールを除去し, 沈殿している RNA に $10 \mu \mathrm{L}$ の RNA フリー水を加えて懸濁した。

回収した RNA4 $\mu \mathrm{g}$, Oligo dT プライマー $0.5 \mu \mathrm{L}$ を加 え, 滅菌水を加えて $8.5 \mu \mathrm{L}$ にメスアップし, $70^{\circ} \mathrm{C}$ で 10 分間加温した。水上で泠却し, SuperScript $\square$ (Thermo Fisher Scientific, Inc.) を用いて逆転写反応 $\left(25^{\circ} \mathrm{C} 10\right.$ 分 , $42^{\circ} \mathrm{C} 50$ 分, $72^{\circ} \mathrm{C} 15$ 分）を行い, cDNA を合成した 得られた cDNA をリアルタイム PCR システム（ Applied Biosystems）を用いて遺伝子発現解析を行った 。炎症性サイトカインの指標として TNF- $\alpha$ (Forward: TCCTTCAGACACCCTCAACC, Reverse: AGGCCCCAGTTTGAATTCTT) を，ハウスキーピング 遺 伝子として $\beta$-actin ( Forward: AGAGCTACGAGCTGCCTGAC, Reverse: AGCACTGTGTTGGCGTACAG）を用いた。

\section{3 結果}

\section{1 大気圧低温プラズマの組成分析}

Fig. 2 より, $\mathrm{He}, \mathrm{OH}, \mathrm{N}^{2}, \mathrm{~N}^{2+}, \mathrm{O}, \mathrm{H}_{\beta}, \mathrm{H}_{\alpha}$ の各 元素のピーク波長が確認された。癌細胞に対して特に 影響を与える可能性がある分子として, OH が挙げら れる。また, デジタルパックテストを用いた培養液中 の過酸化水素濃度測定においても, 印加電圧 $8 \mathrm{kV}$ で は $0.75 \mathrm{mg} / \mathrm{L}, 13 \mathrm{kV}$ では $1.05 \mathrm{mg} / \mathrm{L}$ の過酸化水素が照 射後の培地に溶解していることが判明した。従って， プラズマ中の $\mathrm{OH}$ ラジカルによって培養液中に過酸化 水素が存在し，プラズマ照射による細胞死，増殖抑制 に寄与していることは明らかである。

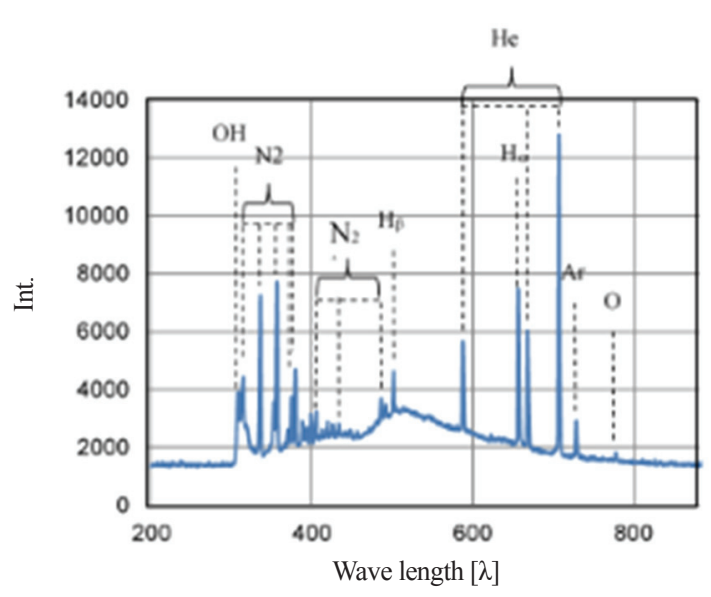

Fig. 2 Raman spectroscopy analysis of plasma. 


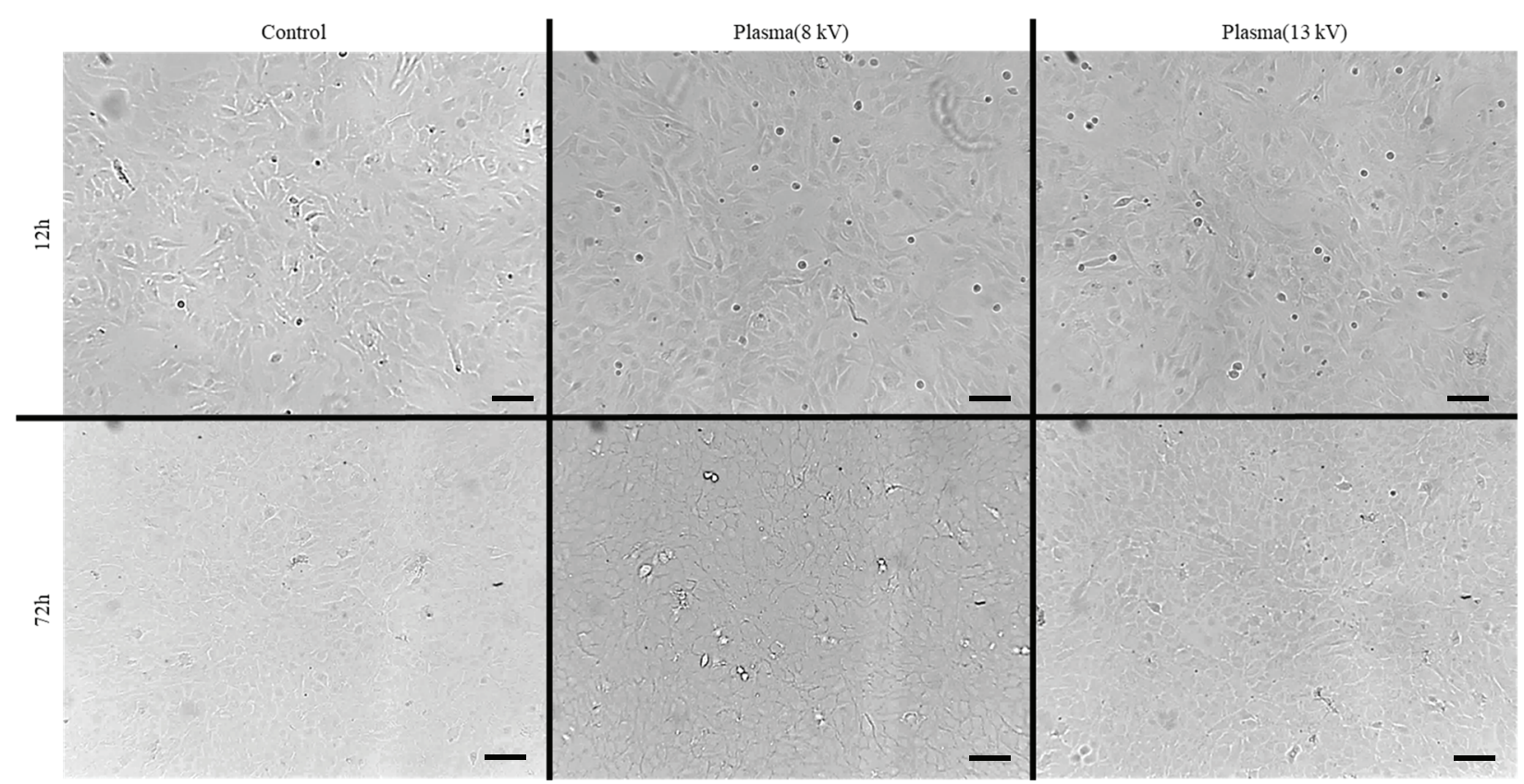

Fig. 3 Micrographic image of MC3T3-E1 cells after plasma irradiation. （Scale bar: $100 \mu \mathrm{m}$ )

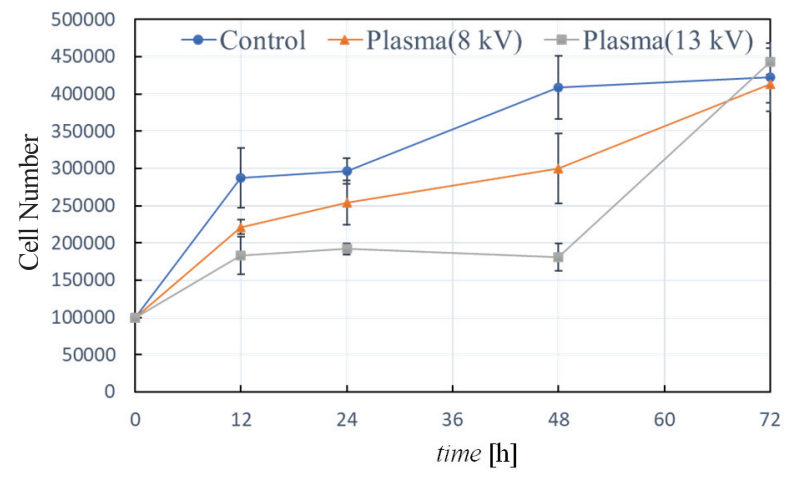

Fig. 4 Cell proliferation after plasma irradiation of MC3T3-E1 cells. ( $n=3$, S.D.)

3.2 正常細胞に対する大気圧低温プラズマ照射培地の 暴露評価

Fig. 3 にプラズマ照射培地暴露後 12，72 時間後の MC3T3-E1 細胞の顕微鏡画像, Fig. 4 に各時間毎の細 胞数の推移を示す。顕微鏡画像では判別しにくいが, 照射 12 時間後ではプラズマ照射群が若干細胞密度が 少なく, 照射 72 時間後ではほぼコンフルエントな状 態まで増殖している。細胞数の推移では, プラズマ照 射 48 後までは対照群と有意な差が生じていたが, 72 時間後においてはどの群もほぼ等しい程度まで増殖し た。

3.3 大腸癌細胞に対する大気圧低温プラズマ照射培地 の暴露評価

Fig. 5 にプラズマ照射培地暴露後 12， 72 時間後の
COLO205 細胞の顕微鏡画像, Fig. 6 に各時間毎の細胞 数の推移を示す。Fig. 5 より, プラズマ照射 12 時間後 ではいずれの群も顕微鏡画像の視野範囲では well 底面 に細胞が付着していた。しかし，72 時間後では対照群 は多くの細胞が底面に付着し増殖しているのに対し, 照射群では細胞数が減少していた。また，印加電圧が $13 \mathrm{kV}$ の群では他の二群と比べて死細胞や細胞壁が崩 壊している細胞が多くみられた。細胞増殖数の推移で は, プラズマを照射した両群において, 対照群と比較 して有意に細胞死，あるいは細胞増殖の抑制が行われ たことが明らかとなった。

\section{4 大腸癌細胞に対する大気圧低温プラズマ照射培地 及び過酸化水素添加培地への暴露評価}

Fig. 7 にプラズマ照射培地暴露及び過酸化水素暴露 96 時間後の顕微鏡画像を示す。対照群は視野すべてに 細胞が存在しており，正常に増殖している。一方，過 酸化水素暴露群では細胞の数は少なく, 黒点のような 死細胞が多く観察された。また，プラズマ照射培地暴 露群では対照群と比べて細胞数が少なく, その形状に おいても変化が生じていた。Fig. 8 に各時間毎の細胞 数の推移を示す。Fig. 8 では, 対照群とその他 2 群で 有意な差が生じていた。また，プラズマ照射培地群と 過酸化水素暴露群でも有意な差が生じており，プラズ マ照射培地暴露群の方が多くの細胞が死滅あるいは増 殖の抑制が生じていた。 


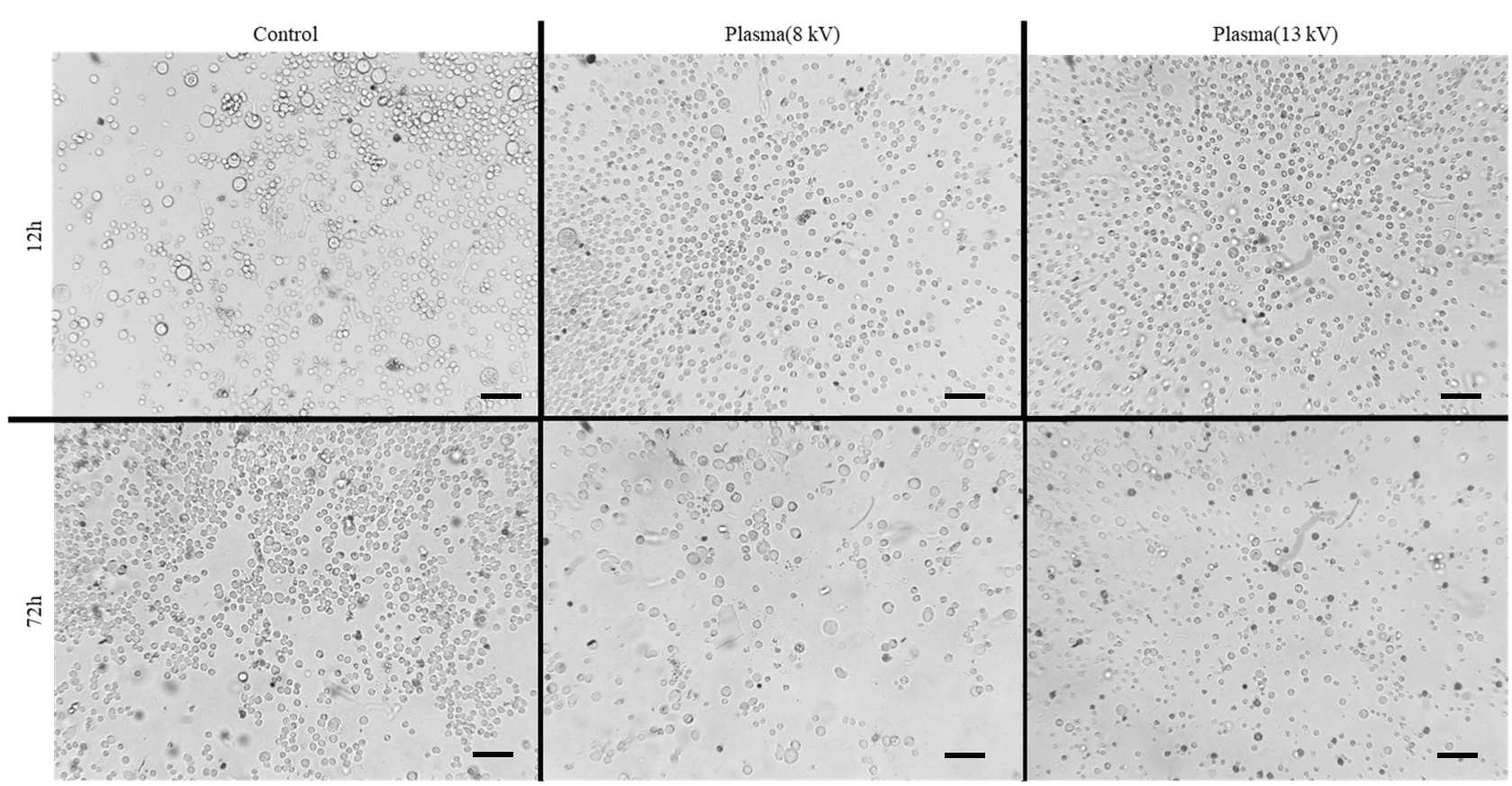

Fig. 5 Micrographic image of COLO 205 cells after plasma irradiation. （Scale bar: $100 \mu \mathrm{m} ）$

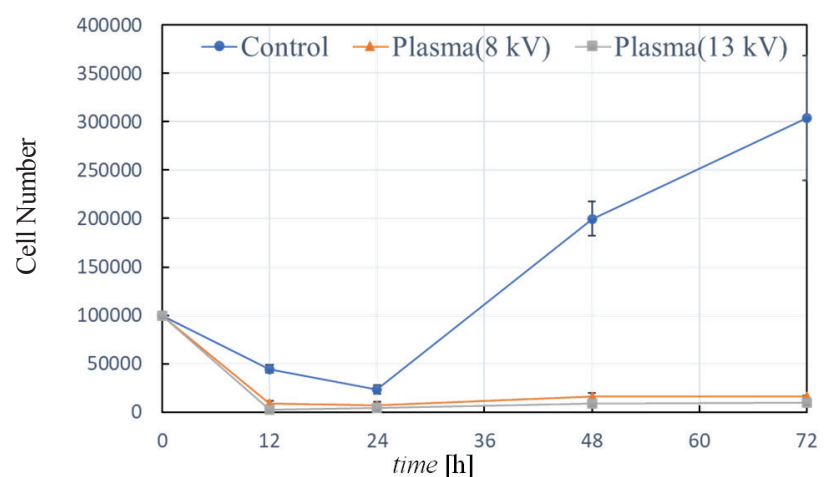

Fig. 6 Cell proliferation after plasma irradiation of COLO205 cells. $\quad(n=3$, S.D. $)$

3.5 大腸癌細胞に対する大気圧低温プラズマ照射培地 暴露群の炎症性サイトカイン比較

Fig. 9-11 に各時間ごとの $T N F-\alpha$ の発現量の比較を 示寸。各時間における $T N F-\alpha$ の值に有意な差は無かっ た。従って, $T N F-\alpha$ 由来の経路での細胞死ではない可 能性が示唆された。

\section{4 考察}

Fig. 4 及び Fig. 6 より，正常細胞と比較して癌細胞で は大気圧低温プラズマの影響が高く，細胞死を誘起す ることが示唆された。Fig. 2 より各種のラジカルが大 気圧低温プラズマでは生成されているため, それらの 抗酸化物質が細胞に対して影響を与えている。正常細 胞ではラジカルの代謝が行われるため, 72 時間後には
対照群と同数まで細胞が増殖している。一方，癌細胞 は正常細胞と比べてラジカルなどの抗酸化物質の代謝 が難しいため，細胞死や増殖の抑制を生じやすい。従 って, 大気圧低温プラズマを大腸癌治療に用いる際に, 他の正常細胞に対して悪影響を与えにくいことが示唆 された。

細胞死の経路を同定するため, 過酸化水素暴露群と の比較を行った結果, 細胞数がプラズマ照射培地暴露 群の方が有意に少なかった。従って，プラズマ照射培 地による細胞死の誘導は， $\mathrm{H}_{2} \mathrm{O}_{2}$ の夕ではなく，複数の 要因が絡み合っていることが明らかとなった。Fig.9-11 では対照群と比較して TNF- $\alpha$ の発現量に変化はなかっ たため, 大気圧低温プラズマによる細胞死は $T N F-\alpha$ に よらない機構で生じていることが分かった。

\section{5 結言}

本稿では，正常細胞と大腸癌細胞に対して大気圧低 温プラズマ培地の暴露を行い，評価を行った。その結 果, 正常細胞では最終的な細胞数に変化はなく,また, プラズマ照射群では大腸癌細胞が優位に減少した。従 って，本研究を用いることで，現在広く行われている 化学療法のような正常細胞に対する影響がなく, 癌細 胞特異的な治療法の開発が可能である。今後は細胞死・ 増殖抑制経路の検討を行っていくとともに, 癌細胞に 対してより効果の高い照射条件などについても調査を 


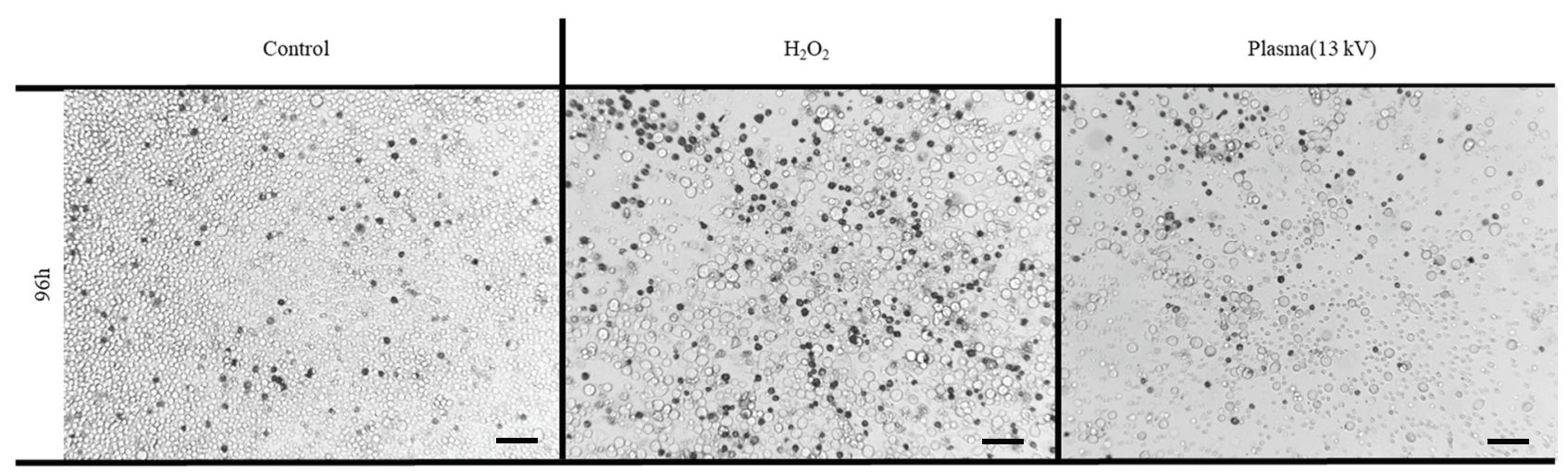

Fig. 7 Micrographic image of COLO 205 cells after plasma and $\mathrm{H}_{2} \mathrm{O}_{2}$ irradiation. (Scale bar: $\left.100 \mu \mathrm{m}\right)$

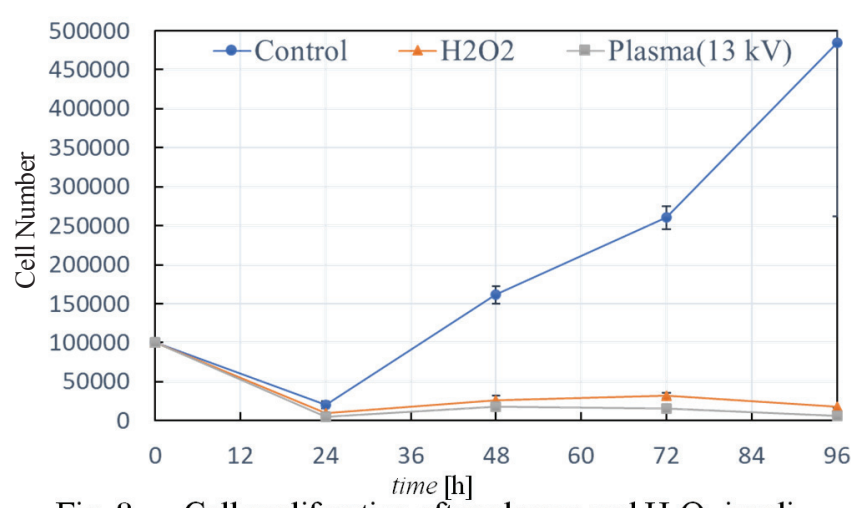

Fig. 8 Cell proliferation after plasma and $\mathrm{H}_{2} \mathrm{O}_{2}$ irradiation of COLO 205 cells. $\quad(n=3$, S.D. $)$

行っていく。

\section{参考文献}

[1] G. Fridman, G. Friedman, A. Gutsol, A. Shekhter, V. Vasilets and A. Fridman, Applied Plasma Medicine, Plasma Processes and Polymers, Vol. 5, Issue 6, pp. 503-533, 2008.

[2] S.Takeda, S.Yamada, N. Hattori, K. Nakamura et al., Intraperitoneal Administration of Plas-ma-Activated Medium: Proposal of a Novel Treatment Option for Peritoneal Metastasis From Gastric Cancer, Annals of Surgical Oncology, Vol. 24, pp.1188-1194, 2017.

[3] F. Bray, J. Ferlay, I. Soerjomataram, R. L. Siegel et al., Global cancer statistics 2018: GLOBOCAN estimates of incidence and mortality worldwide for 36 cancers in 185 countries, CA Cancer J Clin, Vol. 68, Issue 6, pp.394-424, 2018.

[4] 国立がん研究センター, 最新がん統計, https://ganjoho.jp/reg_stat/statistics/stat/summary.html, （参 照 2020-03-31)

[5] T. Hirata, T. Kishimoto, C. Tsutsui, T. Kanai, and A. Mori, Jap anese Journal of Applied Physics, Healing burns using atmospheric pressure plasma irradiation, Vol.56, No.1, Article ID 010302, 2014.

[6] G. Vilema-Enríquez, A. Arroyo, M. Grijalva, R. Israel Ama dor-Zafra and J. Camacho, Molecular and Cellular Effects of Hydrogen Peroxide on Human Lung Cancer Cells: Potential

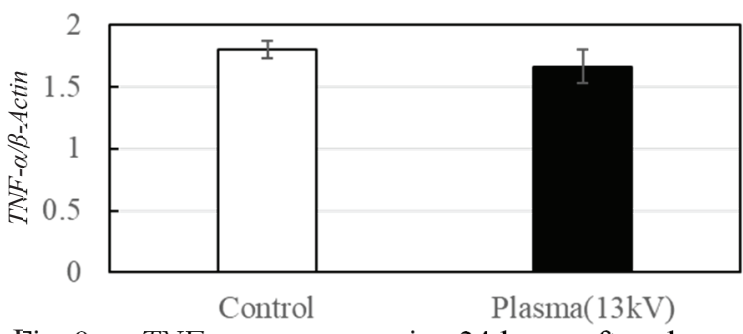

Fig. $9 \quad T N F-\alpha$ gene expression 24 hours after plasma irradiation. $\quad(n=3$, S.D. $)$

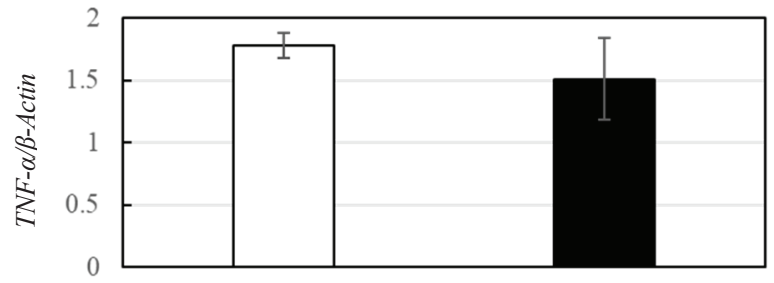

Control Plasma $(13 \mathrm{kV})$

Fig. $10 T N F-\alpha$ gene expression 48 hours after plasma irradiation. $\quad(n=3$, S.D. $)$

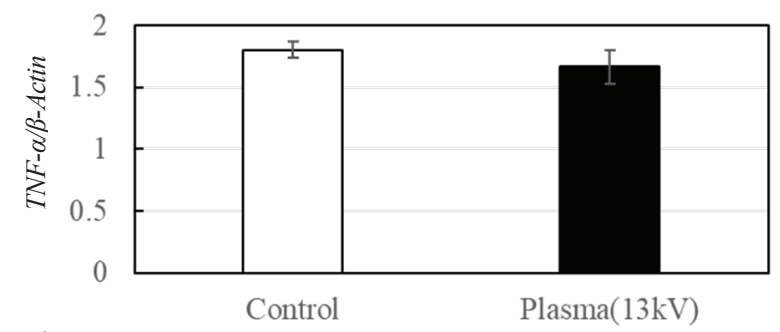

Fig. $11 T N F-\alpha$ gene expression 72 hours after plasma irradiation. $(\mathrm{n}=3$, S.D. $)$

Therapeutic Implications, Oxidative Medicine and Cellular Longevity, Article ID 1908164, 2016.

[7] P. C. Rath, B. B. Aggarwal, TNF-induced signaling in apoptosis, Journal of Clinical Immunology, Vol.19, Issue 6, pp350364, 1999. 